may be due to the internment action of exogenous substance, which diffused into the cytoplasm, in granular structures having no relation to mitochondria and Golgi apparatus.

Dr. Ogawa: These granules increased in number in parallel with the cultural time. (Ogawa et al : 1960). As to the decided mechanisms of lysosome formation, it seems to need further wide histochemical, cytochemical and electron microscopic studies. Your findings of myelın-like structures may coincide with our cytochemical results in terms of a phospholipoprotein nature but on the other hand, Pasteel and his co-workers have shown that the acid phosphatase positive $\beta$-granules were not myelin-like but granular.

Dr. Hosoda : De Duve has shown other enzyme activities such as $\beta$-glucuronidase, RNA-ase and proteinase in lysosome fractions, and, on the other hand, our histochemical studies on spread preparations of subcutaneous tissues of rabbits and mice have revealed the disagreement of the $\beta$-glucuronidase positive granules with those of acid phosphatase. Have you any observation about the localization of these enzymes? How did you differentiate fibroblasts and macrophages?

Dr. Ogawa: We have observed on alkaline phosphatase, acid phosphatase and lipase (by Tween 80 ). Further studies other enzymes will be performed later.

The differentiation of cultured macrophages and fibroblasts is very easy. (Ogawa; 1960)

* Supported by a grant from the Rockefeller Foundation (GA MNS 60236)

Fast Green 染色による赤血球系細胞内の

グロビンの定量について

妹尾左知丸・内海耕慥

\title{
The Quantitative Estimation of Globin in Erythrocytic Cells by Fast Green Staining.
}

\author{
Sachimaru Seno and Kozo Utsumi. \\ The pathological Institute, Faculty of Medicine, Okayama \\ University, Okayama
}

There had been no suitable method for the quantitative estimation of cellular specific proteins, of which synthesis is an important problem in relation to the cell-differentiation and cell-maturation. The authors have succeeded in measuring the quantity of globin in each erythroblast by use of fast green FCF.

The present studies have reported the method and some results about the measurement of globin synthesis in erythroblast of rabbits. 